\title{
Epithelial Antimicrobial Peptides in Defensive Mechanism of Gingiva
}

Mounika $\mathrm{B}^{1}$, J agadish Reddy $\mathrm{G}^{2}$, Harinath Reddy $\mathrm{S}^{3}$, Rajababu P4

Quick Response Code
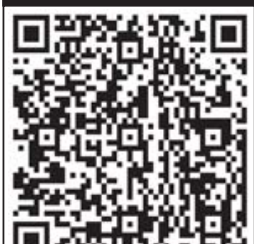

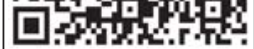

\section{doi: $10.5866 / 2014.641686$}

1Post graduate student

${ }^{2}$ Reader

3Professor

${ }^{4}$ Professor \& HOD

Department of Periodontics

Kamineni Institute of Dental Sciences

Sreepuram, Narketpally, Nalgonda - 508254

\section{Article Info:}

Received: J uly 8, 2014

Review Completed: August 7, 2014

Accepted: November 10, 2014

Available Online: J anuary, 2015 (www.nacd.in)

(c) NAD, 2015 - All rights reserved

Email for correspondence:

smilealwaysmouni@gmail.com

\begin{abstract}
:
Epithelium-derived antimicrobial peptides are one of the components of host defense at mucosal surfaces. They are early responders of the innate immune system that are important contributors in maintaining the balance between health and disease. Gingival epithelium produces natural antimicrobial peptides and proteins constitutively and inducibly in response to bacterial exposure. $\beta$ defensins produced by the epithelium are involved in the initiation and progression, as well as restriction of periodontal tissue destruction, by acting as antimicrobial, chemotactic, and anti-inflammatory agents and also form a foundation for the development of new therapeutic agents. This review focusses on the expression and function of antimicrobial peptides in the oral cavity and their role in the host defense.
\end{abstract}

Key words: Antimicrobial peptides, Bacteria, Defensins, Epithelium, Gingiva, Periodontal disease.

\section{INTRODUCTION}

Oral mucosa is a critical protectiveinterfaceand serves as a barrier to the microbial species present in this unique oral environment. It is the only area of the body in which hard tissues break through the epithelial surface. The epithelium surrounding the tooth is specialized to form an attachment and seal around each tooth, where there is a significant risk of bacterially induced infection and inflammation. ${ }^{1}$ Epithelia, polymorphonuclear leukocytes (neutrophils), and saliva all contribute to the maintaining the health of the oral cavity in overlapping but independent ways. The antimicrobial peptides are early responders of the innate immune system that search and destroy invading pathogens and are important contributors in maintaining the balance between health and disease in this complex environment. ${ }^{2}$ Genes encoding these peptides are expressed in a variety of cells in the host, including circulating phagocytic cells and mucosal epithelial cells, demonstrating a wide range of utility in the innate immune system. 
These peptides represent not only an important component of innate host defense against microbial col onization and a link between innateand adaptive immunity, but also form a foundation for the development of new therapeutic agents. ${ }^{3}$

\section{ROLE OF GINGIVAL EPITHELIUM IN HOST DE FENSE}

In regard to the highly specified cell-to-cell junctions and high renewal capabilities, gingival epithel ium is considered a strong but passive barrier against the bacterial challenge that is constantly present in the oral cavity. ${ }^{4}$ Gingival epithelial cells (GECS) are one of the first host cell types that are in constant contact with bacterial products. ${ }^{5}$ These cells secrete IL-8 and other chemokines and cytokines to alert various cell types and attract neutrophils.

The epithelium is not only a mechanical barrier but, by secreting chemokines and pro-inflammatory cytokines, it also plays a significant role in the initiation and progression of the inflammatory response. They also produce natural antimicrobial peptides and proteins constitutively and inducibly in response to bacterial exposure. These cysteinerich antimicrobial peptides of the epithelium, assumed to contribute to the innate host defense, are called as $\beta$-defensins. Defensins were among the first antimicrobial peptides to be described in mammalians. In humans, defensins consist of two subfamilies, $\alpha$ - and $\beta$-defensins. While $\alpha$-defensins are produced by polymorphonuclear leukocytes and intestinal paneth cells, $\beta$-defensins are produced by epithelial cells. The latter group of defensins was first identified in tracheal epithelial cells two decades ago. ${ }^{6}$

\section{EPITHELIAL ANTIMCROBIAL PEPTIDES}

Epithelium-derived antimicrobial peptides are one of the components of host defense at mucosal surfaces. Direct evidencethat mammalian epithelial cell antimicrobial peptides participate in host defense in the oral cavity was provided by the work of Schonwetter. The first antimicrobial peptide identified in oral epithelium was the $\beta$-defensin, lingual antimicrobial peptide (LAP), described in bovine tongue. Several families of natural antibiotic peptides or proteins are expressed in oral epithelium. These includemembers of the $\beta$-defensin family of peptides, the protein calprotectin (also known as calgranulin), and the multifunctional peptide, adrenomedullin (Table 1 ). ${ }^{7}$

\section{FAMILIES OF HUMAN ANTIMICROBIAL PEPTIDES}

Most antimicrobial peptides are small cationic (polar) molecules with spatially separated hydrophobic and charged regions and molecular weights typically ranging between 3,500 and 6,500 Da. ${ }^{5}$ They have a broad spectrum of antimicrobial activity. Antimicrobial peptides of various families differ in size, amino acid sequence and certain structural motifs.

\section{AMP Structure}

Although AMPs are commonly classified by variation in structural characteristics, there are somestructural features that AMPs share, including a length of less than 60 amino acids, broad spectrum antimicrobial activity at physiological conditions, and an overall positive charge. AMPs can be divided into five sub-categories on the basis of their amino acid composition and structure including anionic peptides, linear amphipathic $\alpha$-helical, cationic peptides enriched for specific amino acids, peptide fragments, and peptides with cysteines that form intramolecular bonding (Table 2). ${ }^{3}$

- The first group composed of anionic peptides similar to the charged-neutral izing pro-peptides of larger zymogens

- The second group-made up contains $\sim 290$ linear cationic $\alpha$-helical peptides, most of which are less than 40 amino acids in length and possess a three dimensional structure with a kink or hinge in the middle.

- The third group consists of approximately 44 peptides all of which are linear in shape and enriched in specific amino acids

- The fourth group is composed of charged peptides that are fragments of larger peptides. 
These peptides possess antimicrobial activity and aresimilar in shapeand size to other AMPs

- The fifth group is composed of $\sim 380$ members which contains conserved 6-cysteine residue motifs forming intramolecular disulfide bonds and $\beta$-sheets. This is an extremely diversegroup of proteins known as defensins ${ }^{8}$, which is hypothesized to have originated in prokaryotes. ${ }^{9}$ This has diverged into plant defensins, arthropod defensins, and the $\beta$ - defensins found in higher animals, including birds, reptiles and mammals. At some point in mammalian evolution the $\alpha$-defensins diverged from the $\beta$ defensin family. A third defensin subfamily, the $\theta$-defensins are found only in rhesus monkeys, having apparently evolved from a mutation in $\alpha$-defensins. ${ }^{10}$

In humans, peptide antibiotics of three families have been identified: the defensins, cathelicidin family member LL-37 in skin and oral mucosa and other epithelia, and histatins (Figure 1).11,12 The human defensins include the $\alpha$-defensins of intestinal and neutrophil origin, and the $\beta$-defensins of skin and oral mucosa and other epithelia. They function by association with the anionic microbial surface, then aggregating to form pores in microbial membranes. In addition to their antimicrobial function, the $\alpha$ and $\beta$-defensins act as chemo attractants for $T$ cells and dendritic cells of the acquired immune system and monocytes. ${ }^{13}$ The $\alpha$ and $\beta$-defensins and LL-37 are local ized in different sites in the gingiva, suggesting that they may serve different roles in the several ecological niches of the periodontium. Thejunctional epithelium is protected by $\alpha$-defensins and LL-37 rel eased from neutrophils, whereas the differentiated stratified epithelia are protected by $\beta$ - defensins. ${ }^{14,15}$

\section{$\alpha$-DEFENSINS}

$\alpha$-defensins are expressed in neutrophils as part of their non-oxidative antimicrobial mechanisms. Alpha- and $\beta$-defensins are peptides with six disulphide-linked cysteines. Structurally, the difference between the two defensins lies within the length of peptide segments between the six cysteines and pairing of the cysteines. Six different human alpha defensins have been identified so far, including four human neutrophil peptides, HNP14, and two others known as human defensins 5 and 6 (HD-5, HD-6) (Figure 2). Within neutrophils, human $\alpha$-defensins are abundant and work together with the oral epithelium to provide a barrier to microbial colonization, particularly in the junctional epithelium of the tooth surface. ${ }^{1}$

\section{$\beta$-DEFENSINS}

$\beta$-defensins 1 and 2 (hBD-1 and hBD-2) (Figure 3) are found in normal, uninflamed gingival tissues as part of the innate host defense mechanism. They are localized at the gingival margin where there is the most exposure to oral bacteria of the plaque on the tooth surface, but not in the junctional epithelium. Thus, the junctional epithelium is protected by $\alpha$-defensins and LL-37 released from neutrophils, while the differentiated, stratified epithelia are protected by $\beta$-defensins. Besides their functions in healthy gingival tissues, $\beta$-defensins are involved in the initiation and progression, as well as restriction of periodontal tissue destruction, by acting as antimicrobial, chemotactic, and antiinflammatory agents. ${ }^{4}$

Human $\beta$-defensins are expressed by various epithelial cell types, including the epithelium of the airways, kidney, skin, cornea, and gingiva. ${ }^{16}$ Four different human $\beta$-defensins (hBD 1-4) have been found and functionally characterized, however, based on genomic targeting, the number of $\beta$-defensins has been suggested to be over $20 .{ }^{17,18}$ Of the four $\beta$-defensins known so far, hBD 1-3 are expressed and secreted in the human oral cavity. ${ }^{19,20}$

\section{Mechanism of antibacterial effect of $\beta$-defensins:}

Microbicidal activities against gram-positive and gram-negative bacteria, fungi, and some parasites are common characteristics of all $\beta$-defensins examined in in vitro conditions. ${ }^{21}$ Like $\alpha$-defensins, human $\beta$-defensins exert their antibacterial effects by permeating the bacterial cellular membrane. Pore formation on the membrane stimulates the leakage of small mol ecules 


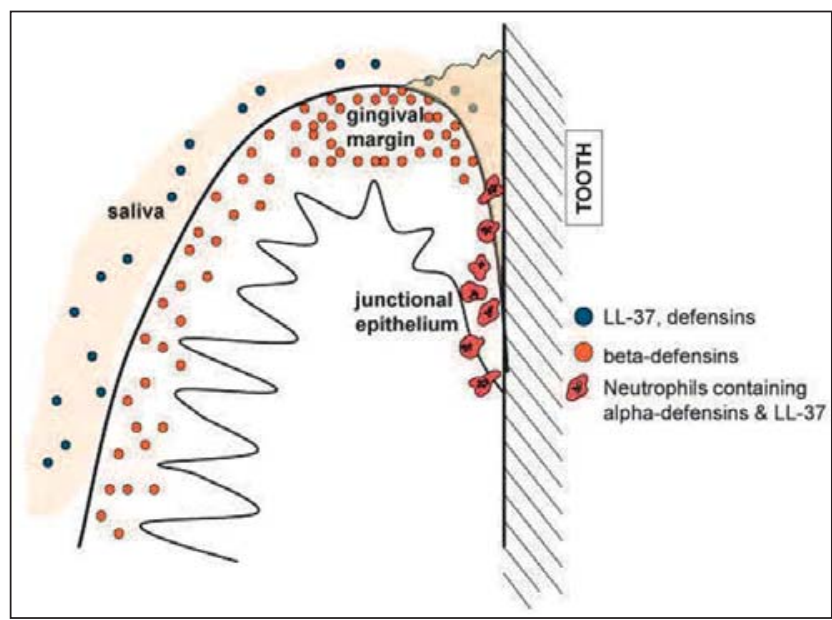

Figure 1: Various sites in the oral cavity where different AMPs are predominantly expressed. (Dale and Fredericks 2005)

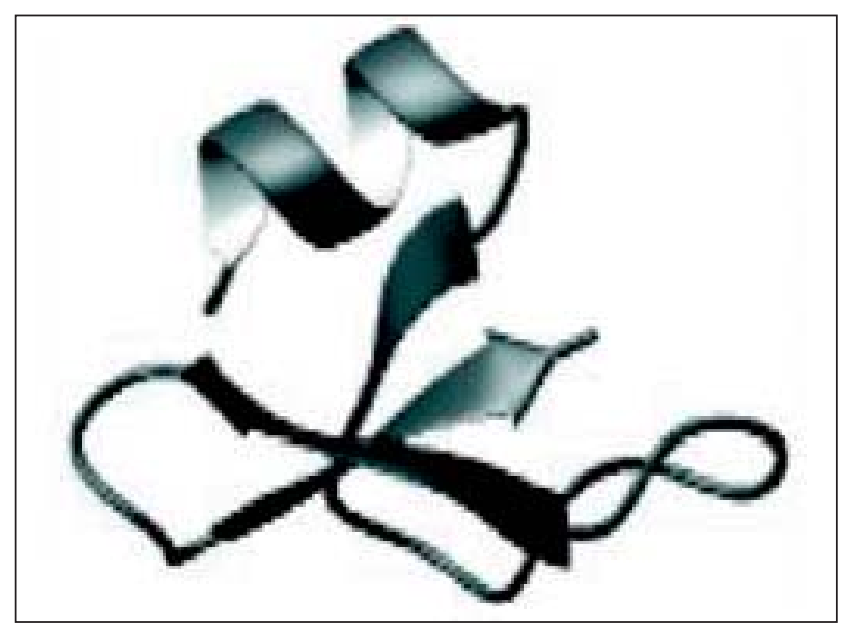

Figure 3: Structure of $\beta$-defensins

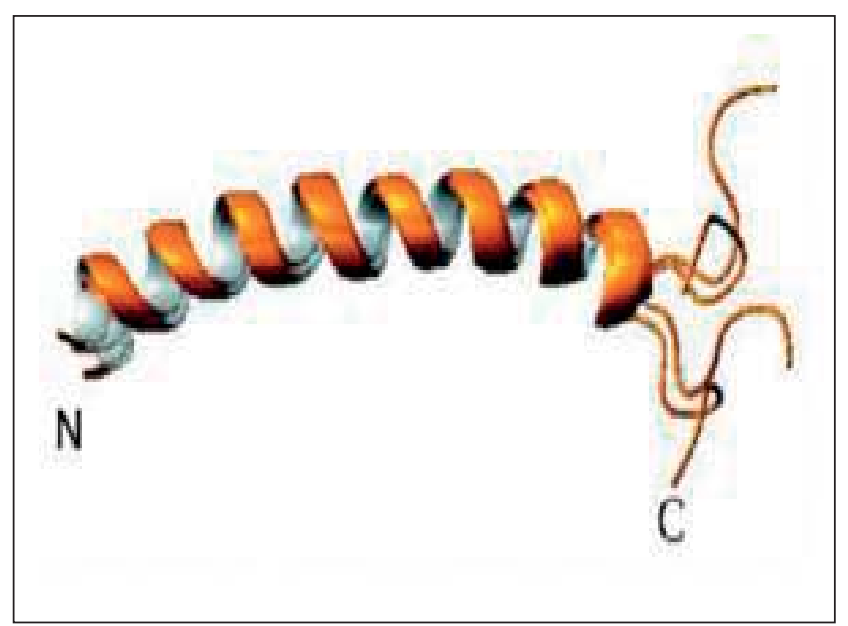

Figure 5: Structure of Cathelicidin Family - LL-37

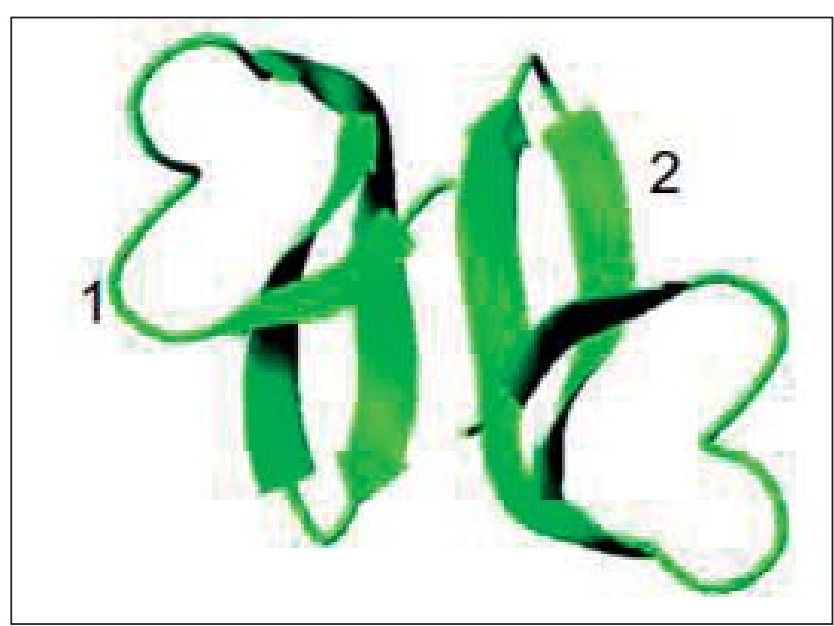

Figure 2: Structure of $\alpha$-defensins

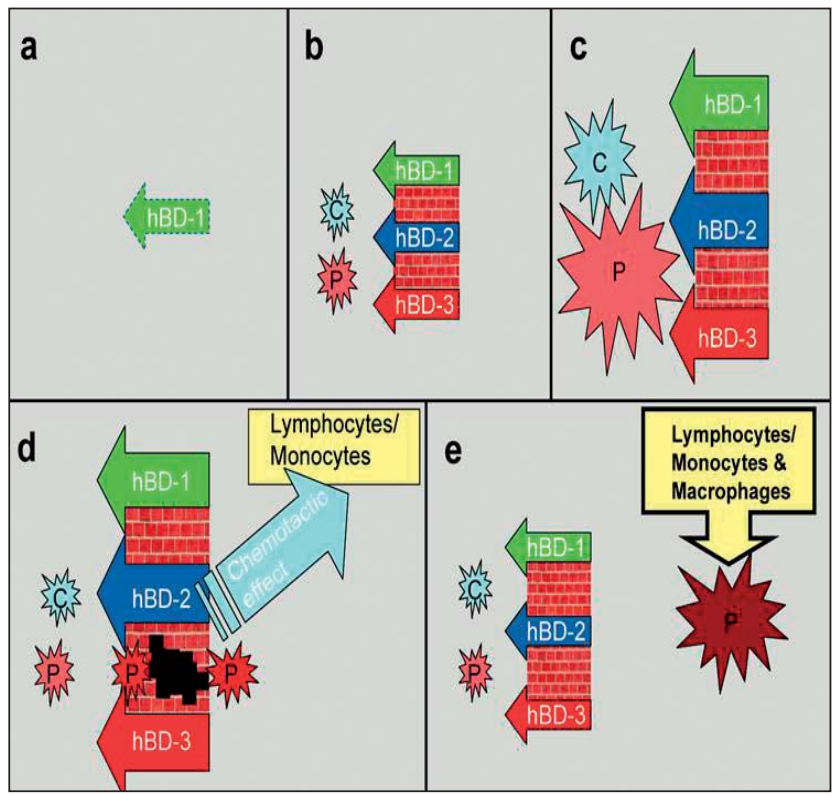

Figure 4: A five-step hypothesis of the recruitment and dismissal of $\beta$-defensins during infection. (a) Within the healthy tissue, epithelial cells secrete only hBD-1, (b) the presence of commensal (C) and pathogenic (P) bacteria induce hBD-2 and hBD-3 secretions from the epithelium, (c) enhanced proportions of bacteria activate the variety of hBD responses, (d) the increasing $\beta$-defensin levels suppress the amount of bacteria, however, some defensin-tolerant pathogenic strains are able to pass through the hBD barrier, when enhanced $\beta$-defensin levels trigger the chemotactic activity through lymphocytes and monocytes, (e) at the final phase, hBD secretions return to the levels seen in a healthy condition, while the second phase of inflammation continues with the interplay between invaded bacteria/bacterial components and immune cells. 
Table 1-ANTIMICROBIAL PEPTIDES EXPRESSED IN THE ORAL CAVITY

\begin{tabular}{|c|c|c|}
\hline Antimicrobial Peptide & Site Of Expression & Role/Comments \\
\hline $\begin{array}{l}\text { HNP1-4 } \\
\text { ( } \alpha \text {-Defensins) }\end{array}$ & $\begin{array}{l}\text { Neutrophils } \\
\text { (azurophilic granules) } \\
\text { Gingival sulcus } \\
\text { Sites of inflammation }\end{array}$ & $\begin{array}{l}\text { Antibacterial, antifungal, and antiviral. } \\
\text { Functional levels in GCF } \\
\text { Expression defective in Morbus } \\
\text { Kostmann syndrome (congenital } \\
\text { neutropenia associated with } \\
\text { periodontal disease) }\end{array}$ \\
\hline LL-37 & $\begin{array}{l}\text { Neutrophils } \\
\text { Gingival sulcus } \\
\text { Saliva }\end{array}$ & $\begin{array}{l}\text { Primarily antibacterial. } \\
\text { Expression is defective in Morbus } \\
\text { Kostmann syndrome. }\end{array}$ \\
\hline $\begin{array}{l}\beta \text {-Defensins } \\
\text { hBD-1 } \\
\text { hBD-2 } \\
\text { hBD-3 }\end{array}$ & $\begin{array}{l}\text { Suprabasal layers of } \\
\text { stratified epithelium; } \\
\text { hBD-1 and hBD-2 absent } \\
\text { in junctional epithelium; } \\
\text { hBD-3 mRNA is widely } \\
\text { expressed but peptide } \\
\text { localization is not known }\end{array}$ & $\begin{array}{l}\text { Antibacterial, antifungal, and antiviral. } \\
\text { Part of the protective barrier function of } \\
\text { epithelium. Secreted, may be associated with } \\
\text { cell or mucosal surface. Also found in salivary } \\
\text { glands and saliva. }\end{array}$ \\
\hline Histatin & $\begin{array}{l}\text { Saliva (parotid and } \\
\text { submandibular) }\end{array}$ & $\begin{array}{l}\text { Antifungal. Histidinerich group of peptides. } \\
\text { Histatin } 5 \text { ( } 24 \text { amino acids) is most active. } \\
\text { Antifungal action requires metabolic activity. }\end{array}$ \\
\hline Adrenomedullin & Epithelium & $\begin{array}{l}\text { Antibacterial, mitogenic, vasodilator, } \\
\text { inducible peptide. }\end{array}$ \\
\hline
\end{tabular}

Table 2: Classes Of Amps (Diamond Et Al. 2009)

\begin{tabular}{|c|c|c|c|c|}
\hline Class & $\begin{array}{l}\text { Structure } \\
\text { Properties }\end{array}$ & Examples & Source (s) & $\begin{array}{l}\text { Physiological } \\
\text { Location }\end{array}$ \\
\hline Anionic & $\begin{array}{l}\text { Negatively } \\
\text { charged }\end{array}$ & $\begin{array}{l}\text { Maximin, } \\
\text { Dermicidin }\end{array}$ & $\begin{array}{l}\text { Amphibians, } \\
\text { humans }\end{array}$ & Airway epithelia \\
\hline Linear & Cationic, $\alpha$-helical & $\begin{array}{l}\text { Cecropin,magainin } \\
\text { pluerocidin }\end{array}$ & $\begin{array}{l}\text { Amphibians, } \\
\text { mammals, insects }\end{array}$ & Skin \\
\hline Linear, Cationic & $\begin{array}{l}\text { Cationic, enriched in } \\
\text { amino acids, extended }\end{array}$ & $\begin{array}{l}\text { Abaecin,I ndolicidin, } \\
\text { histatins }\end{array}$ & Insects,mammals & $\begin{array}{l}\text { Skin, intestinal } \\
\text { epithelium }\end{array}$ \\
\hline Peptide fragments & Cationic, $\beta$-turn & $\begin{array}{l}\text { Lactoferrin, } \\
\text { cathelicidins }\end{array}$ & humans & Blood \\
\hline $\begin{array}{l}\text { Charged peptides } \\
\text { with cysteine }\end{array}$ & $\begin{array}{l}\text { Cationic, anionic, } \\
\text { forms disulfide } \\
\text { bonds, possess } \\
\text { cysteine }\end{array}$ & $\begin{array}{l}\alpha-, \beta-, \text { and } \\
\theta-\text { defensins, } \\
\text { protegrin }\end{array}$ & $\begin{array}{l}\text { Birds, reptiles, } \\
\text { mammals, } \\
\text { plants }\end{array}$ & Ubiquitous \\
\hline
\end{tabular}




\section{Table 3: MEMBRANE AND INTRACELLULAR MODELS OF ANTIMICROBIAL PEPTIDE KILLING AND LYSIS (Brogden 2005)}

\section{Model of antimicrobial activity Synonym Examples of peptides}

TRANSME MBRANE PORE-FORMING MECHANISMS

\begin{tabular}{lll}
\hline Toroidal pore & Wormhole, disk & Magainin 2, protegrin-1, melittin \\
\hline Carpet & LL-37 and MSI-78 \\
\hline & & Dermaseptin S, cecropin, melittin, caerin 1.1 \\
\hline Barrel stave & and ovispirin \\
\hline & Helical-bundle & Alamethicin \\
\hline
\end{tabular}

\section{MODES OF INTRACE LLULAR}

\section{KILLING}

Flocculation of intracellular contents

Alters cytoplasmic membrane

septum formation

Inhibits cell-wall synthesis

Binds nucleic acids

Inhibits nucleic-acid synthesis

Inhibits protein synthesis

Inhibits enzymatic activity

from the bacterial cell that eventually leads to its death.

$\beta$-defensins are broad-spectrum antibacterial peptides, however, their antibacterial effect is considerably salt dependent i.e. their highest activities occur in conditions with low ion concentrations and their antibacterial activities are significantly impaired by the presence of ions, such as $\mathrm{Na}^{-}, \mathrm{Mg} \mathrm{g}^{2-}$, and $\mathrm{Ca}^{2-} .{ }^{22}$ Among the three $\beta$-defensins found in gingiva, hBD- 3 has the lowest sensitivity to salts, being insensitive up to $200 \mathrm{mM} \mathrm{Na}$ concentrations, most probably due to its high positive charge, whereas hBD-1 has the highest sensitivity, being insensitive up to $100 \mathrm{mM} \mathrm{Na}$ concentrations. It is plausible that $\beta$-defensins are inactive against oral bacteria outside the tissues, like in saliva. Beyond their antibacterial effects, $\beta$-defensins are able to neutralize the lipopolysaccharide (LPS) activity of gram-negative bacteria. ${ }^{4}$
Anionic peptides

PR-39, PR-26, indolicidin and microcin 25

Mersacidin

Buforin II and tachyplesin

Pleurocidin, dermaseptin, PR-39, HNP-1, -2 and indolicidin

Pleurocidin, dermaseptin, PR-39, HNP-1, -2 and indolicidin

Histatins, pyrrhocoricin, drosocin and apidaecin

\section{Antimicrobial activities}

These peptides kill micro-organisms by disturbing the integrity of microbial membranes by mechanisms such as pore formation, by iron chelation or by enzymatic disruption of essential microbial target structures. Bacteria do not readily develop resistance against antimicrobial polypeptides in vitro contrary to the development of resistance against conventional antibiotics.

The antibacterial activity of antimicrobial polypeptides is the result of an interaction of polypeptides with bacterial wall components. A major component of the outer wall of Gram-negative bacteria is lipopolysaccharide (LPS). It is well recognised that LPS displays potent proinflammatory activity by direct interaction with host cells. The capacity of various antimicrobial peptides to inhibit this proinflammatory activity may help to shut off the inflammatory reaction initiated by the infectious process. ${ }^{23}$ 


\section{Antimicrobial-peptide-mediated cell killing}

Peptide-mediated cell killing can be rapid. Regardless of the time required, or the specific antimicrobial mechanism, specific steps must occur to induce bacterial killing. ${ }^{24}$ They includeattraction, attachment, peptide insertion and membrane permeability. A number of models have been proposed to explain membrane permeation (Table 3). ${ }^{25}$

\section{Bacterial resistance against $\beta$-defensins}

In response to the challenge by $\beta$-defensins, bacteria exert resistance by forming a capsule, modifying their cell envelope molecules, forming biofilms or cleaving defensins. Porphyromonas gingivalis, a well-known periodontal pathogen, degrades hBD-3 with its gingipains that leads to the inactivation of the peptide. Also some other periodontal bacteria are able to protect themselves from $\beta$-defensins, most probably, by inhibiting the defensin expression pathways. For instance, Treponema denticola inhibits the secretion of hBD2 and hBD- 3 by suppressing the expression of tumour necrosis factor (TNF)- $\alpha$ and toll-like receptor 2 (TLR 2). Hence, the ability of these periodontitisassociated organisms to overcome the $\beta$-defensin challenge seems to be associated with their virulence. ${ }^{26}$

\section{Periodontal bacteria and secretion of $\beta$ - defensins}

The capability of stimulating $\beta$-defensin expressions is strain-dependent and, in particular, dependent on the bacterial association with disease. ${ }^{27}$ A strong correlation exists between the virulence of a periodontal pathogen and its ability to minimize the induction of $\beta$-defensin expression and secretion. In the gingival epithelium, in regard to the constant exposure to microorganisms, $\beta$-defensin genes are activated by only a subset of bacteria and TLR ligands and induced via different pathways. ${ }^{28}$ Therefore, even though the secretion of $\beta$-defensins is a common characteristic of human epithelial cell types, the difference in the cellular origin and regulation of the response should be considered.

\section{$\beta$-defensins in regulation of innate and immune responses}

While hBD-1 is constitutively secreted in the epithelium, hBD-2 and hBD-3 secretions are stimulation-dependent. This stimulation does not necessarily come only from bacteria, since proinflammatory cytokines are also able to induce $\beta$-defensin secretion. In human keratinocytes, proinflammatory cytokines, such as TNF- $\alpha$, interferon (IFN)-ã, interleukin (IL)-1 $\beta$, IL-17, and IL-22, stimulatehBD-2 secretion, whileanti-inflammatory cytokines, IL-4 and IL-10, suppress its production. The relation between $\beta$-defensins and cytokines/ chemokines is bilateral. $\beta$-defensins may have immuno-modulatory effects through connective tissue cells; in in vitro conditions, hBD-2 and hBD3 trigger fibroblast proliferation and more specifically, hBD-3 stimulates cyclooxygenase-2 expression and prostaglandin E 2 synthesis of fibroblasts. ${ }^{29}$ The role of $\beta$-defensins in the immune responseis not only through aggravating it, but also suppressing the response. hBD-3 inhibits the proinflammatory response by inhibiting the secretion of TNF- $\alpha$ from human myelomonocytic cells, while hBD-2 inhibits the I L- 17 production by T-cells. Antiinflammatory effects of hBD-3 are independent on the production of IL-10, a well-known antiinflammatory cytokine. ${ }^{30}$

\section{$\beta$-defensins in gingival wound healing}

Besides their antibacterial and immuneregulatory functions, $\beta$-defensins contribute to the healing process of wounds. Wound healing has four phases: inflammation, re-epithelisation, granulation tissue formation, and tissue remodelling. The re-epithelisation phase requires migration, differentiation, and proliferation of epithelial cells. ${ }^{31}$ hBD-2 and hBD-3, increase keratinocyte migration and proliferation but not hBD-1.

\section{Localization of $\beta$-defensins in gingiva and in organotypic epithelium models}

hBD 1-3 are similar concerning their structures and functions, but they differ from each other in their localizations of expression and secretion. To start with, $\beta$-defensins are not detected in the 
junctional epithelium, but they are secreted and present in the oral and sulcular epithelium. $\beta$ defensin expression in epithelial cells is highly connected to the cellular differentiation. In gingival tissues, mRNAs of hBD-1 and hBD-2 are expressed in the spinous layer, while the peptides are present in the granular layers of the gingiva. On the other hand, hBD-3 localizes in the basal layers of the gingival epithelium. Localization and stimulation patterns of hBD-1, hBD-2, and hBD-3 are very similar in vivo and in vitro; in three dimensional organotypic epithelium models, hBD-1 and hBD-2 are secreted from the superficial layers of the model, while hBD-3 is localized on the basal cell layers. Involucrin, a strong marker of cell differentiation, has similar localization patterns with hBD-1 and hBD-2 in gingiva. ${ }^{4}$

$\boldsymbol{\beta}$-defensins in periodontal health and disease: Several hypotheses have been presented to explain the reason for secretion followed by suppressed expression of $\beta$-defensins during periodontitis (Figure 4). Degradation of $\beta$-defensins by bacteria- or host-derived enzymes and genetic polymorphisms, leading to suppressed expression of defensins, are among the common explanations. ${ }^{4}$

\section{Cathelicidin Family - LL-37}

Cathel icidin AMPs are heterogeneous and share similar characteristics with other AMPs, such as a basic residue, overall amphipathic nature, and a net positive charge at neutral pH. LL-37 (Figure 5), the only member in human cathelicidin family, is transcribed by CAMP (cathelicidin antimicrobial peptide) gene, which translates to an $18 \mathrm{kDa}$ proprotein. This AMP is detected and expressed in higher amounts within neutrophils that migrate through the junctional epithelium to the gingival sulcus. $^{5}$

\section{Potential Therapeutic Value of AMPS}

The mode of antimicrobial activity of AMPs has been most commonly attributed to disruption of cell membranes but Wilmes, Cammue in 2011 reported that defensins can inhibit cell wall biosynthesis via binding and sequestering of lipid II , a building block of bacterial cell wall. ${ }^{32}$ AMPs have several advantages as therapeutics, including the broad spectrum of antimicrobial activity and do not appear to induce antibiotic resistance. ${ }^{33}$ However, limitations as an effective therapeutic are stalled by high production costs and the susceptibility to proteolytic degradation, a mechanism which microbial pathogens secrete proteases to countermeasure the target of AMPs. Due to these limitations, a new pursuit has been made to construct synthetic mimics of AMPs, which would capture the important properties of AMPs but also eliminate problems related to drug therapy.

\section{Anti-Microbial Peptide Mimetics}

Naturally occurring antimicrobial peptides have been proposed as a novel alternative to standard antibiotics because they exhibit broad-spectrum activity with little development of antibiotic resistance. ${ }^{34}$ The natural peptides have been modified to generate peptides with more favourable efficacy/toxicity profiles. An alternate approach is the design and synthesis of peptide mimetics that retain the biological activity of AMPs but are more readily produced, exhibit favourable therapeutic index and are stable under physiological conditions. The development of small molecule antimicrobial peptide mimetics has provided a novel direction for the development of new antibiotics. One such nonpeptide compound $\mathrm{MPE}$ shows low toxicity, is active against clinical isolates, and antibiotic-resistant bacteria. ${ }^{35}$ It is a mimetic whose design was based on the amphiphilic structure of the peptide magainin. This compound was active against numerous oral pathogens, both gram-positive and gram-negative, including biofilm cultures of Streptococcus mutans. It also inhibited the lipopolysaccharide (LPS)-mediated induction of TNF $-\alpha$ from a macrophage cell line, presumably because of its predicted binding of LPS.

Antimicrobial peptide mimetics have numerous advantages over both peptides and agents such as chlorhexidine. Specifically, the mimetics are more stable than peptides, and are protease resistant. They are inexpensive to produce, and exhibit low cytotoxicity. 


\section{Conclusion}

Epithelial cell-derived cationic antimicrobial peptides function to keep the natural flora of microorganisms in a steady state in various body sites (airway, intestine, urogenital tract, oral cavity) and may contribute to the innate host defense against oral microbes and to oral health Altered expression or expression of non-functional GAPs within the oral cavity could render an individual at risk for periodontal disease or other oral disorders. Antimicrobial peptides have emerged as effector substances of the innate immune system against microbial colonization and a link between innate and adaptive immunity involving activities not only as endogenous antibiotics but also as mediators of inflammation and also form a foundation for the development of new therapeutic agents.

$\beta$-defensins constitute major antimicrobial peptides in the initial response against bacteria in gingival tissues. In addition, they function as both pro-inflammatory and anti-inflammatory agents in the periodontal disease pathogenesis. All hBDs play the same role, but in a coordinated manner. Currently, it is considered that the relocalization of $\beta$-defensins in gingiva regulates the host reaction, first by initiating and, at some level, by limiting the immune response.

\section{References}

1. Dale BA, Fredericks LP. Antimicrobial Peptides in the Oral Environment: Expression and Function in Health and Disease. Curr Issues Mol Biol 2005; 7:119-133.

2. Gorr SU. Antimicrobial peptides of the oral cavity Periodontol 2009; 51:152-180.

3. Diamond G, Beckloff N, Weinberg A, and Kisich KO. The Roles of Antimicrobial Peptides in Innate Host Defense. Curr Pharm Des 2009; 15:2377-2392.

4. Gursoy UK, Kononen E. Understanding the roles of gingival $\beta$-defensins. J Oral Microbiol 2012; 4:1-10.

5. Whasun Oh Chung and J onathan Y. An. Periodontal Disease and Gingival Innate I mmunity-Who Has the U pper Hand? Periodontal Diseases - A Clinician's Guide, 2012.

6. Diamond G, Zasloff M, Eck H, Brasseur M, Maloy WL, Bevins CL. Tracheal antimicrobial peptide, a cysteine-rich peptide from mammalian tracheal mucosa: peptide isolation and cloning of a cDNA. Proc Natl Acad Sci USA 1991; 88:3952-3956.

7. Weinberg, Krisanaprakornkit S, Dale BA. Epithelial Antimicrobial Peptides: Review and Significance for Oral Applications. Crit Rev Oral Biol Med 1998; 9:399-414.

8. Boman HG. Innate immunity and the normal microflora. I mmunol Rev 2000; 173:5-16.

9. Zhu S. Evidence for myxobacterial origin of eukaryotic defensins. Immunogenetics 2007; 59:949-954.

10. Selsted ME. Theta-defensins: cyclic antimicrobial peptides produced by binary ligation of truncated $\alpha$-defensins. Curr Protein Pept Sci 2004; 5:365-371.

11. Hancock RE and Scott MG. The role of antimicrobial peptides in animal defenses. Proc Natl Acad Sci 2000; 97:8856-8861.

12. Selsted ME and Ouellette AJ . Mammalian defensins in the antimicrobial immune response. Nat I mmunol 2005; 6:551557.

13. Territo MC, Ganz T, Selsted ME, Lehrer R. Monocytechemotactic activity of defensins from human neutrophils. J Clin Invest 1989; 84:2017-2020.

14. McKay MS, Olson E, Hesla MA, Panyutich A, Ganz T, Perkins $S$ et al. Immunomagnetic recovery of human neutrophil defensins from the human gingival crevice. Oral Microbiol Immunol 1999; 14:190-193.

15. Dale BA, Kimball J R, Krisanaprakornkit S, Roberts F, Robinovitch M, O Neal R et al. Localized antimicrobial peptide expression in human gingiva. J Periodontal Res 2001; 36:285-294.

16. Devine DA. Antimicrobial peptides in defence of the oral and respiratory tracts. Mol I mmunol 2003; 40:431-443.

17. Marshall RI. Gingival defensins: linking the innate and adaptive immune responses to dental plaque. Periodontol 2004; 35:14-20.

18. Lehrer RI. Immunology: Peptide gets in shape for selfdefence. Nature 2011; 469:309-310.

19. Gomes Pde S, Fernandes MH. Defensins in the oral cavity: distribution and biological role. J Oral Pathol Med 2010; 39:1-9. 
20. Vardar-Sengul S, Demirci T, Sen BH, Erkizan V, Kurulgan E, Baylas H. Human beta defensin-1 and -2 expression in the gingiva of patients with specific periodontal diseases. J Periodontal Res 2007; 42:429-437.

21. Yang D, Liu ZH, Tewary P, Chen Q, Rosa G, Oppenheim J J . Defensin participation in innate and adaptive immunity. Curr Pharmaceutic Des 2007; 13:3131-3139.

22. Bowdish DM, Davidson DJ, Hancock RE. Immunomodulatory properties of defensins and cathelicidins. Curr Top Microbiol Immunol 2006; 306:2766.

23. Hiemstra PS. Epithelial antimicrobial peptides and proteins: their role in host defence and inflammation. Paediatr Respir Rev 2001; 2:306-310.

24. Matsuzaki. K, Murase $\mathrm{O}$, Miyajima. K. Kinetics of pore formation by an antimicrobial peptide, magainin 2, in phospholipid bilayers. Biochemistry 1995; 34:12553-2559.

25. Brogden. KA. Antimicrobial peptides: pore formers or metabolic inhibitors in bacteria? Nat rev Microbiol 2005; 3:238-250.

26. J oly S, Maze C, McCray PB J r, Guthmiller J M. Human $\beta$ defensins 2 and 3 demonstrate strain-selective activity against oral microorganisms. J Clin Microbiol 2004; 42:10241029.

27. Vankeerberghen A, Nuytten H, Dierickx K, Quirynen M, Cassiman J J , Cuppens H. Differential induction of human beta-defensin expression by periodontal commensals and pathogens in periodontal pocket epithelial cells. J Periodontol 2005; 76:1293-1303.

28. Diamond G, Beckl off N, Ryan LK. Host defense peptides in the oral cavity and the lung: similarities and differences. J Dent Res 2008; 87:915-927.

29. Chotjumlong $P$, K hongkhunthian S, Ongchai S, Reutrakul V, Krisanaprakornkit S. Human $\beta$-defensin-3 up-regulates cyclooxygenase-expression and prostaglandin E2 synthesis in human gingival fibroblasts. J Periodontal Res 2010; 45:464-470.

30. Semple F, Webb S, Li HN, Patel HB, Perretti M, J ackson IJ et al. Human $\beta$-defensin 3 has immunosuppressive activity in vitro and in vivo. Eur J Immunol 2010; 40:1073-1078.

31. Hakkinen L, Uitto VJ , Larjava $\mathrm{H}$. Cell biology of gingival wound healing. Periodontol 2000; 24:127-152.

32. Hancock RE and Diamond G. The role of cationic antimicrobial peptides in innate host defences. Trends Microbiol 2000; 8:402-410.

33. Zasloff M. Antimicrobial peptides of multicellular organisms. Nature 2002; 415:389-395.

34. Hua J, Scott RW, Diamond G. Activity of antimicrobial peptide mimetics in the oral cavity: II. Activity against periopathogenic biofilms and anti-inflammatory activity. Mol Oral Microbiol. 2010; 25:426-432.

35. Gorr SU, Abdolhosseini M. Antimicrobial peptides and periodontal disease. J Clin Periodontol 2011; 38:126-141.

\title{
Gain quick access to our journal online View our journal at
}

\author{
www.nacd.in
}

